\title{
Zelfdoding en de waarde van een rationeel leven
}

\author{
Fleur Jongepier
}

ANTW 110 (4): 453-472

DOI: 10.5117/ANTW2018.4.004.JONG

\section{Abstract \\ Suicide and the value of a rational life}

In recent Kantian discussions about suicide, it is not uncommon to find relatively 'mild' approaches towards suicide. Even though as a rule suicide is still impermissible, some argue that there may be circumstances that can make suicide morally permissible. If a person suffers such that she cannot be considered to have a rational life any more, suicide is no longer immoral because the object of the moral duty is no longer present. In this paper, I investigate this argumentative strategy by exploring what it might mean to have a'rational life'. I argue that on a minimal conception, people who suffer unbearably still lead rational lives and suicide is thus not morally justified. On substantial conceptions, however, not only does having a rational life become a contingent affair, it also leads to a more liberal approach towards suicide than 'mild Kantians' may be prepared to accept.

Keywords: Kantianism, suicide, unbearable suffering, rational life

\section{$1 \quad$ Inleiding}

Heeft iemand het recht zichzelf van het leven te ontnemen? Het antwoord hierop is volgens burgerinitiatief Uit Vrije Wil een volmondig 'ja'. Ze beroepen zich hierbij, in hun manifest, op het zelfbeschikkingsrecht:

Onze Grondwet garandeert iedere Nederlandse burger de vrijheid zijn leven naar eigen inzicht en voorkeur in te richten en daarover beslissingen te nemen. 
Deze vrijheid omvat ook de laatste levensfase en beslissingen over sterven en dood. Op niemand rust de plicht tot leven.

Veel filosofen stellen echter grenzen aan het zelfbeschikkingsrecht. Volgens J.S. Mill bijvoorbeeld - de liberaal pur sang - is jezelf als slaaf verkopen een uitzondering op de liberale regel. Het is geen vrijheid om ervoor te kiezen je eigen vrijheid op te heffen (Mill 1859: 170). Volgens Mill kan er dus een spanning optreden tussen het zelfbeschikkingsrecht enerzijds en waarvoor dat recht wordt gebruikt anderzijds. Er zijn instanties mogelijk, zoals slavernij, waarbij iemands vrije handeling diezelfde vrijheid om zeep lijkt te helpen, en om die reden twijfelachtig of zelfs immoreel is. ${ }^{1}$

In dit artikel wil ik deze spanning onderzoeken zoals deze optreedt in het vraagstuk rondom zelfdoding. Dit thema speelt een belangrijke rol in de geschiedenis van de ethiek en politieke filosofie, omdat het een mogelijk grensgeval lijkt te zijn van vrijheid of autonomie, en de vraag op scherp stelt of we aan onszelf iets moreel verplicht zijn. Meer specifiek zal ik de spanning onderzoeken door te kijken naar de hedendaagse Kantiaanse discussie daarover, omdat de spanning in die literatuur expliciet wordt besproken en het meest is uitgewerkt.

Een mogelijke Kantiaanse benadering van zelfdoding is de 'strenge' optie: zelfdoding is principieel en in alle gevallen uit den boze. Als het zo is dat de bron van moraal gelegen is in ons vermogen praktisch te delibereren, dan is het vernietigen van dat vermogen ontoelaatbaar. Veel hedendaagse Kantianen pleiten echter voor een mildere benadering ten aanzien van zelfdoding en pleiten voor uitzonderingen op deze regel (Hill 1991; Langton 1992; Korsgaard 1996, 2009; Cholbi 2010; Velleman 2015). Sommigen beweren bijvoorbeeld dat zelfdoding moreel legitiem is wanneer er sprake is van ondraaglijk lijden. Een terugkomend argument voor zo'n mildere benadering is dat bepaalde omstandigheden het vermogen voor praktisch delibereren zodanig aantast dat er geen sprake meer is van een 'rationeel leven'. ${ }^{2}$ Er blijft dus niets meer over dat gerespecteerd zou moeten worden, om die reden zou zelfdoding in die gevallen legitiem zijn. ${ }^{3}$ De centrale vraag die ik

1 Zowel David Archard (1990: 462-63) als David Schwan (2013: 765) beargumenteren overigens dat Mill's argument wat betreft de illegitimiteit van slavernij niet ook op gaat voor zelfdoding. 2 De term 'rationeel leven' zal in dit artikel als vertaling worden gebruikt van de Engelse term '(rational) agency'. Met de termen 'rationele natuur' of 'praktische natuur' zal ik hetzelfde bedoelen.

3 Sommigen zijn zelfs zo vindingrijk geweest om te beweren dat we volgens de Kantiaanse ethiek de plicht hebben tot zelfdoding in bepaalde gevallen, zoals vergevorderde dementie (Cooley 2007), een misvatting die Michael Cholbi recentelijk heeft rechtgezet (Cholbi 2015). 
zal behandelen is of deze mildere benadering succesvol is. Kan een 'milde Kantiaan' die zelfdoding in de regel als immoreel beschouwt dit toch bij uitzondering toestaan op basis van een idee van wat het betekent een rationeel leven te leiden?

Ik zal beargumenteren dat de milde Kantiaan in een dilemma terechtkomt, afhankelijk van hoe het concept van een 'rationeel leven' wordt ingevuld, en dat het uitzonderingsargument een weinig hoopvolle manier is zelfdoding in bepaalde omstandigheden legitiem te achten. Dus ofwel moeten Kantianen alsnog alle gevallen van zelfdoding afwijzen, ofwel moeten ze zich bedienen van een andersoortig argument om zelfmoord onder bepaalde omstandigheden alsnog als moreel toelaatbaar te kunnen beschouwen.

De opzet is als volgt. In de eerste sectie sta ik eerst kort stil bij het basale idee dat zelfdoding een handeling is die zichzelf zou ondermijnen of een interne contradictie inhoudt. Het is niet mijn ambitie iets aan de (enorme) literatuur hieromtrent toe te voegen, maar enkel een grove schets te geven waarom zelfdoding voor Kantianen prima facie immoreel zou zijn. In sectie twee bespreek ik het 'uitzonderingsargument' op basis van de notie van een rationeel leven en beargumenteer dat een minimale interpretatie van wat het betekent een rationeel leven te leiden bijna geen enkele instantie van zelfdoding kan legitimeren. In de daaropvolgende sectie evalueer ik meer substantiële interpretaties van wat het zou kunnen betekenen een rationeel leven te leiden, waaronder een narratieve interpretatie. Ik beargumenteer dat deze interpretatie niet langer een universele beschrijving lijkt te bieden, en bovendien het bereik van toegestane zelfdoding juist te ruim maakt. ${ }^{4}$ Dat wil zeggen, op een substantiële interpretatie wordt het onmogelijk gemaakt bepaalde zelfdodingen als moreel ontoelaatbaar te beschouwen en dus een 'middenpositie' in te nemen. In de vierde en laatste sectie neem ik een stap terug en probeer ik een diagnose te bieden van waarom de middenpositie instabiel is, en geef ik een ruwe schets van een mogelijke alternatieve benadering.

4 Mijn doel in dit artikel is een interne kritiek te geven op mild Kantianisme. Wanneer ik in dit artikel spreek over een te klein of juist een te groot bereik wat betreft moreel toelaatbare zelfdodingen, gaat het me dus om een bereik dat voor de milde Kantiaan ofwel te klein ofwel te groot is. 


\section{$2 \quad$ Kant(ianen) over zelfdoding}

Het is bekend dat Kant buitengewoon streng was in zijn veroordeling van zelfdoding. 'Degenen die de legitimiteit van zelfdoding verdedigen doen de samenleving enorme schade aan. Stel dat de dispositie tot zelfdoding iets was dat personen zouden koesteren, of dat zelfdoding een recht was, of zelfs een verdienste of eer - zulke personen zouden voor iedereen weerzinwekkend zijn', zo valt in zijn Lectures on Ethics (27:372) onder andere te lezen. En in The Metaphysics of Morals schrijft Kant: 'Het uitroeien van het subject van de moraal in ieders eigen persoon is het uitroeien van het bestaan van de moraal zelf' (6:423, eigen vertaling). Zelfdoding is volgens Kant het 'meest verschrikkelijke dat denkbaar is', het 'allerergste wat een persoon zichzelf kan aandoen', de 'hoogste schending van de plichten die we aan onszelf hebben'. Wanneer we met een zelfdoding geconfronteerd worden is de juiste reactie 'afschuw of haat'. ${ }^{5}$ Dit strenge oordeel is ook van toepassing wanneer de (wens tot) zelfdoding voortkomt uit doffe ellende, wanneer iemand zo ongelukkig is en zo levensmoe dat enkel de dood nog iets is waarnaar verlangd wordt. Maar waarom?

In de Fundering voor de metafysica van de zeden, waar Kant verschillende formuleringen van de categorische imperatief uiteenzet, bespreekt Kant zelfdoding als een 'testcase' van hoe de categorische imperatief toegepast zou kunnen worden. Als we uitgaan van de natuurwetformule van de categorische imperatief, wat kunnen we dan zeggen over de (on)toelaatbaarheid van zelfdoding? Kant schrijft:

Iemand ervaart een afkeer van het leven ten gevolge van een serie van kwalen die hem geen enkele hoop meer overlaat. Maar hij is nog in zoverre in het bezit van zijn rede dat hij zich zelf kan afvragen of het niet toch in strijd zou zijn met de plicht jegens zichzelf om zich van het leven te beroven. Hij probeert nu of de maxime van zijn handeling wel een algemene natuurwet zou kunnen worden. Zijn maxime is echter: uit eigenliefde hanteer ik het principe om mijn leven te bekorten wanneer het op langere termijn meer kwaad dan genoegen belooft. Het is alleen nog de vraag of dit principe van eigenliefde een algemene natuurwet zou kunnen worden. Men ziet dan echter snel: een natuur, wier wet het zou zijn op grond van dezelfde gewaarwording waarvan

5 Dit zijn citaten gebruik uit Kants Lectures on Ethics die ook worden gebruikt door Jennifer Uleman (2016) en Michael Cholbi (2010). Ik realiseer me dat het gebruik van Kants Lectures ter discussie staat. Ik wil dan ook benadrukken dat ik niet de ambitie heb in dit artikel stelling te nemen wat betreft Kants eigen positie ten aanzien van zelfdoding. 
het de bestemming is tot bevordering van het leven aan te sporen, het leven zelf te vernietigen, zou zichzelf tegenspreken en dus niet als natuur bestaan. Dientengevolge zou die maxime onmogelijk als een algemene natuurwet kunnen bestaan en bijgevolg is zij geheel in strijd met het bovenste principe van alle plicht. $(\mathrm{G}, \mathrm{IV}, 421-2)^{6}$

Kant stelt zich de vraag of een persoon die zelfdoding uit eigenliefde overweegt zijn maxime voor handelen kan universaliseren, dat wil zeggen, of deze maxime tegelijkertijd een universele wet zou kunnen zijn (zie ook Mertens 2017). Kants antwoord is nee: de maxime loopt uit op een zelfcontradictie. Hoe deze contradictie precies moet worden uitgelegd en of er eigenlijk überhaupt sprake is van een contradictie, is een punt van veel discussie (Korsgaard 1985; Gunderson 2004; Brassington 2006; Uleman 2016). Het lijkt bijvoorbeeld niet direct evident dat iemands maxime om zelfdoding te plegen ondermijnd wordt wanneer iedereen zelfdoding zou plegen, of tenminste toch zeker niet op dezelfde manier waarop liegen ondermijnd wordt wanneer iedereen zou liegen omdat er dan niet meer zoiets als 'leugens of 'waarheid' zou zijn. Michael Cholbi schuift het argument dat zelfdoding op basis van eigenliefde niet universaliseerbaar is zelfs geheel terzijde, omdat een 'heel koor van Kantianen en Kant-critici' bepaald niet onder de indruk zijn van dit argument (Cholbi 2010: 491).

Niettemin denken veel Kantianen dat er, wanneer het gaat over zelfdoding, wel degelijk ergens een contradictie te vinden is, zo niet in de universele wet-formulering van de categorische imperatief, dan wel ergens anders. Een mogelijke en zeer grove uitleg van de contradictie is dat de rationele wil de bron is van moraal, dat zelfdoding een uitroeiing betekent van die rationele wil, en dit samengenomen betekent dat iemand niet consistent de wil kan hebben haar rationele wil uit te roeien. ${ }^{7}$

David Velleman (2015) legt de contradictie uit als een instantie van 'praktische irrationaliteit', en maakt de volgende vergelijking. Laten we aannemen dat geld instrumenteel waardevol is: het is waardevol omdat het een middel is tot geluk. Geldwolven, echter, worden ongelukkig van hun jacht naar meer geld. Geldwolven maken dus volgens Velleman de fout om hun doel op te geven voor het middel. Iemand die zelfdoding overweegt omwille van zijn of haar welzijn, maakt volgens Velleman dezelfde fout: ook zij geeft een doel (leven) op voor een middel (welzijn), dus ook hier is er sprake

6 De vertaling van deze passage is van Thomas Mertens (2008).

7 Mijn doel is hier niet iets nieuws aan deze discussie toe te voegen, maar slechts een schets te geven van waarom zelfdoding vanuit de Kantiaanse ethiek prima facie immoreel zou zijn. 
van praktische irrationaliteit. Het idee is dat geluk, maar ook ongeluk, alleen kan bestaan bij gratie van precies datgene waaraan een einde wordt gebracht door zelfdoding. De 'waarde' van het leven is kortom een noodzakelijke mogelijkheidsvoorwaarde voor geluk en ongeluk, om die reden kan (on)geluk zelf geen reden zijn om het leven te beëindigen.

Twee dingen moeten hier worden opgemerkt. Ten eerste, wanneer het gaat over het 'leven' als noodzakelijke mogelijkheidsvoorwaarde gaat het niet om een biologisch leven maar een rationeel leven. Een van de redenen hiervoor is dat juist de moraal de opoffering van het biologische leven kan vereisen (Uleman 2016). Jennifer Uleman verwijst daarbij naar een voorbeeld van Kant waarbij executie geprefereerd zou moeten worden boven het geven van een valse getuigenis. Zelfdoding is dus in principe immoreel omdat het rationele leven (iets van onconditionele waarde) zelf als het ware op de weegschaal wordt gelegd.

Ten tweede gaat het niet om zelfdoding in zijn algemeenheid, maar om een specifieke reden voor zelfdoding: het gaat om gevallen waarbij zelfdoding overwogen wordt omdat het leven niet meer 'opweegt'. Korsgaard (2009) stelt bijvoorbeeld dat zelfdoding plegen om toekomstig ongeluk te voorkomen een wezenlijk ander soort handeling is dan zelfdoding om iemand te redden. Als de eerste handeling immoreel is, hoeft de tweede dat nog niet te zijn. Het type zelfdoding dat veel Kantianen als moreel problematisch zien, en die - zo zal ik aannemen - de milde Kantiaan inderdaad niet als legitiem wil beschouwen, zijn zelfdodingen waaruit, zoals Thomas Hill het formuleert, een 'consumenten-perspectief' (1991: 98) spreekt. De meest extreme variant hiervan is wat hij de 'hedonistisch gecalculeerde' (1991: 90) zelfdoding noemt, waarbij tot zelfdoding wordt overgegaan na een zekere kosten-batenanalyse. Zulke gevallen zijn, als ze al bestaan, uiterst zeldzaam. Maar ook wat we zouden kunnen noemen 'liberale zelfdodingen', waarbij een persoon tot de conclusie komt 'het is wel goed zo' en haar leven 'voltooid' acht, zou vanuit (bovenstaand) Kantiaans perspectief moreel problematisch zijn. Er spreekt eveneens een 'consumentenperspectief' uit, ook al is er misschien geen sprake van een uitgewerkte kosten-batenanalyse. ${ }^{8}$

8 Zoals Govert den Hartogh terecht opmerkt is de term 'voltooid leven' een "ongelukkig eufemisme" omdat het suggereert dat "het leven een klus is die op een gegeven ogenblik wel geklaard is" (2013: 6). Maar ook bij personen met een voltooidlevenwens is er doorgaans sprake van ernstig lijden met een medische grondslag. Tegelijkertijd is er in de samenleving wel degelijk het idee aanwezig dat het moreel legitiem is een eind te maken aan het leven en/of daarbij hulp van een arts te krijgen ook wanneer er geen sprake is van een medische grondslag. Dit is wat ik bedoel met de term "liberale zelfdoding". De voltooidlevendiscussie heeft natuurlijk vooral betrekking op het 
Samenpakkend kunnen we stellen dat de maxime om tot zelfdoding over te gaan 'omwille van welzijn' zou moeten leiden tot een contradictie met datgene wat voor die maxime moet worden verondersteld, namelijk het rationele leven. Als we aannemen dat het hebben van een rationeel leven van intrinsieke of onconditionele waarde is (Korsgaard 1986), kan deze waarde niet worden opgegeven voor iets dat enkel van conditionele waarde is, zoals (on)geluk. De vervolgvraag is nu: wat betekent het nu precies om een rationeel leven te leiden? Wanneer is daarvan niet langer sprake? Het antwoord op deze vraag bepaalt immers voor een belangrijk deel welke handelingen al dan niet met het principe in strijd zijn en bepaalt meer in het bijzonder in welke gevallen zelfdoding bij uitzondering moreel toelaatbaar zou zijn.

\section{$3 \quad$ Uitzonderingen op de regel}

In deze sectie wil ik kijken naar wat ik het 'uitzonderingsargument' zal noemen. Interessant aan dit argument is dat precies het beroep op de morele relevantie van een rationeel leven, wat op verschillende manieren voor Kantianen de bron vormt om zelfdoding in de regel te veroordelen, ook reden geeft om daarop uitzonderingen te maken en dus bepaalde zelfdodingen moreel toelaatbaar te achten. De gedachte is: wanneer je niet meer in staat bent een rationeel leven te leiden, dan vormt zelfdoding niet langer daarop een inbreuk.

Wellicht niet geheel ontoevallig komen de meeste Kantianen die een mildere benadering ten aanzien van zelfdoding toestaan vaak uit op de redenen voor zelfdoding die ongeveer overeenkomen met de redenen die vaak als legitiem worden gezien voor euthanasie, zoals dat er sprake moet zijn van ondraaglijk lijden. Hill ziet ondraaglijk lijden bijvoorbeeld als een situatie waarin zelfdoding toelaatbaar is, omdat het hierbij gaat om een geval waarbij 'the life that is ended lacks the potential for rational, autonomous agency' (1991: 101). ${ }^{9}$ In omstandigheden van uitzichtloos lijden is iemand onvoldoende in staat gebruik te maken van zijn 'human capacities' (1991; 101), waarmee

\footnotetext{
al dan niet uitbreiden van de euthanasiewet, maar het lijkt me plausibel dat personen die vinden dat ze een recht zouden moeten hebben op euthanasie omdat ze 'klaar' zijn met leven, ook zouden vinden dat zelfdoding om die reden moreel legitiem is.

9 Overigens is voor Hill zelfdoding niet immoreel, maar kunnen we wel een Kantiaans moreel ideaal formuleren waaraan we onze intuïties over wanneer zelfdoding legitiem is en wanneer niet, zouden kunnen toetsen (Hill 1991: 95, 101).
} 
Hill bedoelt zijn rationele vermogens. Ook Velleman ziet ondraaglijk lijden als mogelijke uitzondering op de Kantiaanse regel. Wanneer iemands pijn van zo'n aard is dat het zijn hele leven bepaalt en hij geen enkel ander doel kan nastreven dan het bestrijden of voorkomen van pijn, dan is dit aldus Velleman geen geval meer waarin het rationele leven wordt afgewogen tegen andere (conditionele) waarden. Het is eerder een geval waar het rationele leven zelf ondermijnd wordt (Velleman 1999: 2015, 34-35). Het uitzonderingsargument kan schematisch als volgt worden samengevat:

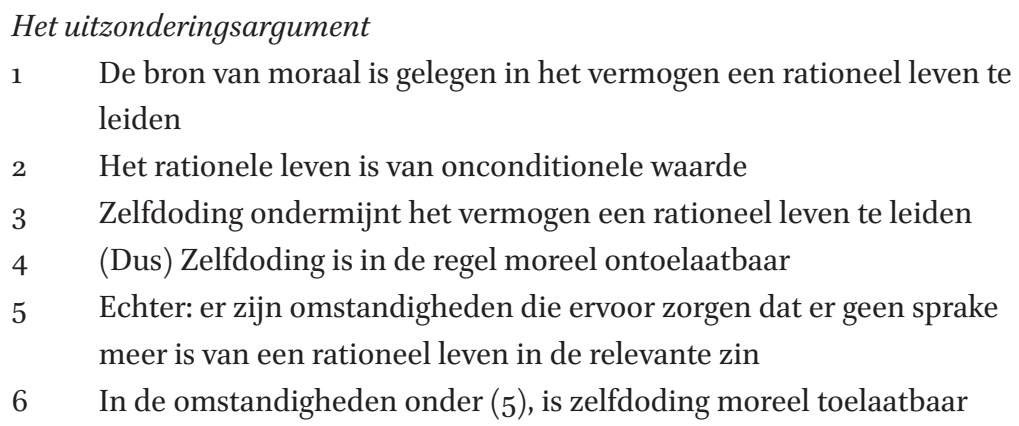

Op alle afzonderlijke stappen valt genoeg te zeggen, maar ik wil hier 1-4 als gegeven nemen, en mij vooral toeleggen op stap 5 . In welke omstandigheden kunnen we niet langer spreken van een rationeel leven? De toevoeging 'in relevante zin' is hierbij van belang. Er zijn verschillende concepties van wat het betekent een rationeel leven te leiden, en het succes van het uitzonderingsargument hangt er vanaf welke interpretatie we hanteren.

De meest gangbare conceptie van wat het betekent een rationeel leven te leiden is een minimale conceptie. Veel Kantianen benadrukken bijvoorbeeld wanneer ze uitleggen om wat voor rationeel vermogen het hen te doen is, dat we zeker niet moeten denken aan het vermogen verstandige beslissingen maken, of dat deze capaciteit alleen aan de hoogopgeleide elite is voorbehouden. Korsgaard beroept zich bijvoorbeeld op het idee dat het gaat om het vermogen om een 'reflectieve afstand' te nemen van je verlangens en driften (Korsgaard 1985: 93) en de capaciteit om doelen te stellen (1985: 187). Deze capaciteit is volgens Korsgaard onvermijdelijk. Om die reden kunnen de relevante rationele vermogens ook niet te dik worden ingevuld, want dan zouden ze voor sommige personen helemaal niet onvermijdelijk zijn. Ook Hill benadrukt dat hij iets minimaals in gedachten heeft wanneer hij de vraag stelt wat het betekent om een rationeel wezen te zijn. Namelijk, simpelweg datgene dat de mens van lagere dieren onderscheidt (Hill 1991, 96). Het gaat om een 'bescheiden set van capaciteiten' (1991: 97). 
Iemand die niet over de relevante rationele capaciteiten beschikt, is volgens hem een wezen dat überhaupt geen doelen of principes heeft en dat volledig door instinct wordt gestuurd. ${ }^{10}$ Bij een dergelijke minimale karakterisering van wat het betekent een rationeel leven te leiden, gaat het dus grofweg om een leven van een wezen dat in staat is praktisch te delibereren. Een rationeel wezen is een wezen dat zichzelf doelen kan stellen en kan reflecteren over de middelen om die doelen te bereiken. Een rationeel leven is een leven van een wezen dat in staat is afstand te nemen van zijn of haar impulsen en verlangens, en te reflecteren of hij of zij daarop wil handelen of niet.

Deze beschrijving van onze rationele natuur is geen empirische claim over dat we ook daadwerkelijk met grote regelmaat deze 'afstand' tot onze driften kunnen innemen. Het feit dat mensen doorgaans tamelijk 'irrationeel' zijn in de meer gangbare zin van het woord, vormt daarom hierop dan ook geen objectie. Het gaat erom dat het voor mensen onvermijdelijk is om zich praktische vragen te kunnen stellen over de doelen die ze zich stellen of over de verlangens waarop ze al dan niet besluiten te handelen (wat onder andere verklaart waarom we het iemand kwalijk nemen wanneer hij zich 'slaafs' laten leiden door zijn driften).

Het voordeel van een dergelijke minimale conceptie is dat iedereen zo begrepen een rationeel leven leidt. Wie van ons streeft er nu geen doelen na, hoe klein of kortdurend ook? Maar zo'n minimale conceptie is tegelijkertijd niet onproblematisch. Het probleem is dat het moeilijk zo niet onmogelijk is om op basis van een minimale invulling te komen tot de gezochte uitzonderingen op de regel wat betreft zelfdoding. Met andere woorden, de minimale interpretatie van wat het betekent een rationeel leven te leiden, leiden niet tot de conclusie dat zelfdoding in bepaalde omstandigheden legitiem zou zijn. Waarom niet? Omdat er haast geen omstandigheden denkbaar zijn die een rationeel leven minimaal begrepen, ondermijnen. Ook iemand die ondraaglijk lijdt, helse pijn ervaart, chronisch ziek is, meerdere zintuiglijke vermogens is verloren, enzovoorts, is nog altijd - en daaruit bestaat precies de tragiek - een rationeel wezen in minimale zin. Zoveel blijkt

10 Hill noemt hier opvallend genoeg als voorbeeld ook wezens die incoherente doelen of principes hebben, hun eigen doelen of principes niet kunnen opvolgen, blind de verwachtingen en bevelen van anderen (of van hunzelf) opvolgen of die behalve pijn en genot om niets geven. Dit lijken me substantieel andere invullingen van wat het betekent om niet over de relevante rationele capaciteiten te beschikken dan de eerstgenoemde voorbeelden. Dit is dus een mogelijk voorbode dat er geschoven wordt of op zijn minste onduidelijkheid bestaat over de interpretatie van de relevante notie. 
uit het feit dat deze personen hun lijden of doodswens als reden zien voor handelen; als reden zien om euthanasie aan te vragen.

Misschien kan van personen die in een opwelling overgaan tot zelfdoding gezegd worden dat van de relevante praktische capaciteiten geen sprake meer is (al is zelfs dat maar de vraag). Echter, de meeste personen die euthanasie aanvragen kunnen helder denken en zijn verre van impulsief (zie ook Govert den Hartogh 2016). Bovendien, het feit dat 'impulsieve' zelfdodingen mogelijk wél legitiem zouden zijn (want: geen sprake meer van een rationeel leven) en weldoordachte zelfdodingen niet (want: wel sprake van een rationeel leven) is eveneens een ongemakkelijke uitkomst.

De contrastklasse van wezens die niet over de relevante capaciteiten beschikken, zijn wezens die de slaaf zijn van hun impulsen of totaal geen doelen kunnen formuleren, zoals individuen die een frontale lobotomie hebben ondergaan (Nussbaum 1995: 117). In dat geval lijkt het duidelijk dat we op basis van een argument over het leiden van een rationeel leven niet tot de gewenste, 'milde' conclusies kunnen komen wat betreft zelfdoding. Er is, ook bij ondraaglijk lijden, nog altijd sprake van een rationeel leven, en daarom sprake van een capaciteit die gerespecteerd dient te worden en niet moedwillig vernietigd mag worden.

Wil de uitzonderingsstrategie dus slagen, dan moet de uitleg van de notie van een rationeel leven 'dikker' zijn dan, bijvoorbeeld, slechts de capaciteit om reflectieve afstand te nemen van onze verlangens en driften. Op dit punt kan de milde Kantiaan van tactiek veranderen, en een meer substantiële invulling van de relevante praktische vermogens overwegen.

\section{Substantiëlere benaderingen van een rationeel leven}

De beweging om de notie van een rationeel leven 'dikker' in te vullen, is niet per se ad hoc. We zouden ons immers kunnen afvragen waarom we in eerste instantie zouden moeten denken dat een minimalere conceptie van een rationeel leven de meer plausibelere conceptie zou moeten zijn. Maar een minimalere conceptie van wat het betekent een praktisch wezen te zijn is daarmee nog niet per se een minder controversiële conceptie (de Maagt 2017). Sterker nog, hoe minimaler hoe controversiëler ze zou kunnen zijn. Stel dat we de capaciteit voor praktisch delibereren en doelen nastreven begrijpen als iets dat zich niet in de toekomst uitstrekt; dat voor het hebben van deze capaciteit alleen nodig is om twee opties en niet meer te hebben; dat het alleen noodzakelijk is om doelen te formuleren maar niet daarop te kunnen handelen. Deze meer 'minimale' invullingen zijn niet, omdat ze 
minimaler zijn, minder controversieel. Er zijn dus wellicht goede redenen om een minder uitgeklede notie van wat het betekent een rationeel leven te leiden, te overwegen.

Een mogelijkheid is de notie van een rationeel leven te begrijpen in termen van het voortbestaan van iemands specifieke identiteit en de waarden die hij/zij erop nahoudt. Hill bespreekt bijvoorbeeld zelfdodingen die gemotiveerd worden om te ontsnappen aan een leven dat iemand zelf onwaardig acht. Hij suggereert dat zelfdoding niet per se ontoelaatbaar is wanneer iemands leven op een fundamentele manier in strijd is met haar conceptie van hoe zij wil leven en geen mogelijkheid meer ziet om zodanig te leven dat ze 'trouw' kan blijven aan zichzelf. Volgens Hill zien sommigen het leven als prostitué, bedelaar, verslaafde, kannibaal of slaaf als zodanig (Hill 1991: 91). Als iemand noodgedwongen zo'n leven zou moeten leiden, dan is zelfdoding een legitieme keuze. Een ietwat soortgelijke beweging is te vinden in Korsgaards Sources of Normativity, waarin ze schrijft dat zelfdoding soms 'de enige manier kan zijn om je identiteit te behouden, en de waarden te beschermen waarvoor je hebt geleefd' (Korsgaard 1996: 162). ${ }^{11}$

Maar deze dikkere invulling is niet erg hoopvol. Het is misschien plausibel om te denken dat je minstens een praktische identiteit hebt. Heb je die niet, dan leid je wellicht geen rationeel leven. Maar daaruit volgt nog niet dat specifieke praktische identiteiten waardevol of waardeloos zijn (die van een bedelaar of kannibaal), laat staan dat zelfdoding in die gevallen al dan niet legitiem zou zijn. Een beroep op een specifieke praktische identiteit legt misschien uit wat iemands prudentiële redenen zijn om tot zelfdoding over te gaan, maar geeft niet direct een overtuigend antwoord op de vraag waarom we morele redenen zouden hebben om zelfdoding in dergelijke gevallen legitiem te achten.

Een andere mogelijke 'dikkere' interpretatie van wat het betekent een rationeel leven te leiden, is een narratieve interpretatie. Je zou kunnen zeggen dat het niet slechts gaat om het kunnen formuleren en nastreven van doelen en kritisch reflecteren op je verlangens, maar om het vertellen van je eigen levensverhaal. Hill lijkt zich op een bepaald moment op een dergelijke narratieve benadering te beroepen. Hij merkt op dat iemand die overgaat tot zelfdoding zijn of haar rationele leven in feite 'verkort'. Gezien het duidelijk is dat het ook niet gaat om een biologisch leven dat verkort

11 Het is overigens maar zeer de vraag of Korsgaard zich in Hill's argumentatie kan vinden, er kunnen immers volgens Korsgaard morele redenen zijn om niet te handelen op de redenen die voortvloeien uit iemands praktische identiteit. Ik zal hier verder niet op in gaan. 
wordt, moet het dus gaan om een narratieve 'duur' van een leven. De keuze tot het verkorten van het leven, gaat Hill verder, kan juist een manifestatie zijn van autonomie en een ultieme beslissing zijn van wat het betekent de 'auteur' van een levensverhaal te zijn (1991: 101). Iemand kan ervoor kiezen dat verhaal tot een eind te brengen met de idealen volgens welke zij zelf wilde leven: 'If you value being an author and have just one story to write, you should not hurry to conclude it. But sometimes, to give it the meaning you intend, you must end it before you spoil it.' (1991: 101).

Hoe hoopvol is het idee dat onze rationele natuur 'narratief' van aard zou zijn? Dit zit hem uiteindelijk in de details - er is immers niet zoiets iets als 'één' narratieve benadering. Maar de algemene schets zoals die door Hill wordt gegeven heeft in elk geval een aantal problemen. Ten eerste kan men vraagtekens stellen bij de universaliteit van zijn claims. Galen Strawson (2004) stelt bijvoorbeeld dat hij zichzelf en zijn leven helemaal niet op een narratieve manier begrijpt, eerder 'episodisch'. Hij ziet zichzelf niet als de auteur van een levensverhaal, en beargumenteert dat hetzelfde geldt voor onder andere Bob Dylan, Fernando Pessoa, Iris Murdoch, Michel de Montaigne en veel Boeddhisten. Het zou weinig respectvol zijn, aldus Strawson, om te zeggen dat deze personen in relevante zin geen rationeel leven zouden leiden of een gebrekkig zelfinzicht zouden hebben. ${ }^{12}$

Ook als Strawsons kritiek onterecht is, is een narratieve benadering zoals die van Hill problematisch. Deze benadering lijkt namelijk voor veel meer speelruimte (uitzonderingen) te zorgen dan Hill voorziet en dan de milde Kantiaan zou willen accepteren. Zoals we hebben gezien willen bovengenoemde Kantianen doorgaans zelfdodingen als illegitiem beschouwen wanneer die gepleegd worden vanuit een 'consumenten perspectief'. In die gevallen wordt de onconditionele waarde van het leven afgewogen tegen iets van conditionele waarde (zoals ongeluk). Maar waarom zou iemand die terugblikt op zijn of haar leven, de balans opmaakt en concludeert: 'Het is wel goed geweest, zo', niet precies als de auteur van haar levensverhaal optreden, zoals Hill suggereert? Het is met andere woorden niet duidelijk hoe je met een narratieve benadering nog de zelfdodingen kunt uitsluiten die in beginsel door bovengenoemde Kantianen als problematisch worden gezien. Als het hebben van een rationeel leven inhoudt dat je de auteur

12 Ik wil niet suggereren dat Strawsons kritiek op alle narrativiteitstheorieën van toepassing is, enkel dat hij een terechte kritiek levert op het voorstel van Hill volgens welke we de auteurs zijn van ons eigen levensverhaal dat we zelf tot een einde kunnen brengen. Daarmee is niet gezegd dat er mildere, meer plausibelere narratieve benaderingen zijn die niet vatbaar zijn voor Strawsons kritiek. 
bent van je eigen levensverhaal, en dat je dat verhaal zelf tot een einde mag brengen, dan wordt het bereik van de toegestane zelfdoding dus te groot, tenminste wanneer men eraan vast wil houden zelfdodingen om welzijnsoverwegingen ('het is wel genoeg zo') als immoreel te beschouwen.

We kunnen daarom stellen dat de Kantiaan die een mildere benadering ten aanzien van zelfdoding wil verdedigen, in een dilemma terecht komt. Wanneer een beroep wordt gedaan op het idee van een rationeel leven, en deze notie wordt minimaal begrepen, dan is het bereik van toegestane zelfdoding te klein. Ook personen die ondraaglijk lijden hebben een rationeel leven, en dus is zelfdoding niet legitiem. Als aan de andere kant de notie substantiëler wordt begrepen, dan is de beschrijving niet langer universeel en wordt het bereik (voor de Kantiaan) te ruim.

Op dit punt kunnen we ons afvragen: zijn de bovengenoemde substantiële alternatieven niet gewoon evident implausibel? Valt er werkelijk niet een 'gematigde' conceptie van wat het betekent een rationeel leven te leiden te bedenken, en dus aan het dilemma te ontsnappen? In een recent artikel over hoe je als Kantiaan bepaalde zelfdodingen kunt legitimeren, suggereert Michael Cholbi (2010) dat wat het betekent om over de relevante rationele vermogens te beschikken inhoudt dat iemand een 'rationele conceptie van haar eigen welzijn' kan articuleren, ofwel, in meer Rawlsiaanse termen, dat zij er een 'conceptie van het goede' op nahoudt (Cholbi 2010, 506 ). Een wezen dat niet in staat is een conceptie van het goede te articuleren, leidt dus in relevante zin geen rationeel leven. Daar kan volgens Cholbi sprake van zijn bij ondraaglijk lijden. Voor een persoon die ondraaglijk lijdt, schrijft Cholbi, waartoe hij ook zwaar depressieve personen rekent, is zelfdoding in moreel opzicht legitiem, omdat het object waarop de morele plicht normaliter betrekking heeft niet meer volledig aanwezig is (Cholbi 2010: 507).

Maar ook hier zien we dat dezelfde spanning optreedt. Alles staat of valt in dit geval met hoe 'dun' of hoe 'dik' we nu vervolgens de notie van een conceptie van het goede moeten begrijpen. Als het hebben van een conceptie van het goede substantieel invullen, dan vervallen we in dezelfde problemen als voor de narratieve benadering. ${ }^{13}$ Als iedereen die (tijdelijk) niet in staat is een 'levensplan' op te stellen, of niet in staat is zijn of haar waardeoordelen consistent met elkaar te maken, geen conceptie heeft van het goede, dan zou zelfdoding in al die gevallen dus legitiem zijn. Maar

13 Bijvoorbeeld wanneer, zoals Rawls schrijft, dit betekent dat iedereen een "more or less determinate scheme of final ends" zou moeten hebben (Rawls 1996: 19-20). 
daarmee wordt het bereik voor milde Kantiaan die een middenpositie wil verdedigen weer te ruim, aannemende dat ze aan een bovengrens willen vasthouden. Tegelijkertijd is een minimale interpretatie van wat het betekent een conceptie van het goede te hebben, ook geen optie. Minimaal begrepen heeft ook de persoon die het tellen van grassprietjes ziet als enige doel in het leven een conceptie van het goede (Rawls 1971: 432).

Het probleem is duidelijk: hoe minimaler en dus universeler we de notie maken, hoe moeilijker het wordt om geloofwaardig te maken dat bijvoorbeeld personen die ondraaglijk lijden geen conceptie zouden hebben van het goede leven. Het enige dat personen die ondraaglijk lijden nog willen, is het stoppen met willen (Vanhaute 2009). Maar ze willen nog altijd iets, en denken dat dit iets het beste voor hen is. Dus waarom zou dit niet gewoon een zogenaamde 'limiting case' zijn van het hebben van een rationele conceptie van je eigen welzijn? Deze personen zijn nog steeds in staat om over hun eigen wensen en welzijn na te denken, ook al komen ze tot de paradoxale conclusie dat niet meer bestaan hetgeen is wat goed voor hen is. ${ }^{14}$ Als dat klopt, dan is zelfdoding in die gevallen niet legitiem, omdat er in dat geval nog wél het object aanwezig is waar de morele plichten op van toepassing zijn.

Kortom, de middenpositie is instabiel. De milde Kantiaan heeft dan twee keuzes: ofwel terug te gaan naar een 'strenge' benadering waarbij zelfdoding altijd immoreel is en waarop geen uitzonderingen zijn te maken, ofwel juist te kiezen voor een liberale benadering, en accepteren dat zelfdoding ook in veel minder strikte omstandigheden toelaatbaar is en er bijvoorbeeld geen sprake hoeft te zijn van ondraaglijk lijden.

\section{$5 \quad$ Diagnose en een mogelijk alternatief}

Het is duidelijk dat we steeds terugkomen in hetzelfde spanningsveld waarbij de betekenis van een rationeel leven voor de milde Kantiaan steeds ofwel een te klein ofwel een te groot bereik oplevert. Dit heeft alles te maken met het paradoxale aspect dat ten grondslag ligt aan de doodswens zelf. Wanneer we zelfdoding immers zien als een keuze die gemaakt wordt op basis van redenen, dan is het moeilijk vol te houden dat die persoon niet

14 Rawls' grassprietjesteller-voorbeeld is niet alleen een filosofisch gedachte-experiment. Pasman et al. schrijven bijvoorbeeld dat er artsen zijn die het feit dat iemand alleen nog in staat is te fietsen of te lezen, aangaven als reden dat iemand niet ondraaglijk lijdt (Pasman et al. 20o9). 
voldoet aan de relevante voorwaarden voor wat het betekent een rationeel leven te leiden. Maar als we zeggen dat iemand in relevante zin geen rationeel leven leidt, dan kunnen we eigenlijk ook niet spreken van een 'keuze', 'wil' of 'handeling' van die persoon. Dan is het dus ook onzinnig om te spreken over de legitimiteit van die handeling, omdat er überhaupt geen sprake is van een handeling in de relevante zin. Zoals Velleman opmerkt, zijn de condities voor wat het betekent om een rationeel, autonoom leven te leiden ook de condities die nodig zijn om een rationele, autonome keuze te maken (Velleman 1999: 7). Als die condities afwezig zijn, dan zijn de condities die nodig zijn voor een beslissing om te kwalificeren als rationeel en autonoom, eveneens afwezig. Kortom, we kunnen niet én zeggen dat zelfmoord legitiem is (omdat de relevante rationele capaciteiten zijn weggevallen), én zeggen dat personen in staat zijn daarover autonome beslissingen te maken, precies omdat die capaciteiten zijn weggevallen. Een vervelende Catch-22.

Waar gaat het nu mis? Om deze vraag te beantwoorden moeten we terug naar een van de eerste aannames die ten grondslag ligt aan het uitzonderingsargument zoals ik dat heb besproken. Dit is de aanname dat een rationeel leven op zichzelf van intrinsieke of onconditionele waarde is een invloedrijke aanname die terug te vinden is in veel Anglo-Amerikaanse Kant interpretaties (zie b.v. Korsgaard 1986). Alleen als men deze aanname maakt, volgt dat zelfmoord prima facie immoreel is. Alleen dan kom je in de spanning terecht tussen respect voor de rationele vermogens van mensen enerzijds, en een specifiek gebruik van diezelfde rationele vermogens - zelfdoding - anderzijds. Alleen als men deze aanname maakt, is het nodig om een uitzonderingsargument te maken om bepaalde zelfdodingen alsnog te legitimeren. Want zolang de aanname in stand wordt gehouden, zal zelfdoding altijd in de regel moeten worden afgekeurd, en kunnen de enige uitzonderingen op de regel instanties zijn waarbij er niet langer sprake is van een rationeel leven.

Moet de Kantiaan bovenstaande aanname maken? Niet per se. In elk geval is het idee dat Kant er zelf een 'waarde-gebaseerde' opvatting van onze rationele natuur op nahield niet oncontroversieel (Nyholm 2016). Als we de aanname zouden laten varen, zou dat ook een andere benadering ten aanzien van de legitimiteit mogelijk maken, omdat zelfdoding niet meer 'in de regel' immoreel zou zijn. Je zou, grofweg, kunnen denken dat wat in moreel opzicht gerespecteerd dient te worden, het rationele vermogen is van personen om hun eigen doelen te formuleren en daarnaar te handelen. Als personen niet zijn gemanipuleerd en vrij zijn hun eigen doelen te kunnen formuleren, dan is er niet direct een reden het zeer specifieke 
en paradoxale doel van zelfdoding, als immoreel te beschouwen. Als dus iemands intentie om een eind te maken aan het leven niet voortkomt uit dwang, en als deze persoon daarbij het welzijn van anderen om hem/haar heen niet ernstig schaadt, dan is er dus niet per se iets immoreels aan de hand. Alan Gewirth stelt bijvoorbeeld een dergelijke benadering voor:

In zoverre een persoon die zelfdoding overweegt voldoet aan de condities van wat het betekent om te handelen in strikte zin, waaronder de afwezigheid van innerlijke oorzaken die ervoor zorgen dat hij geen controle heeft over zijn eigen gedrag, ziet hij er nog steeds op toe dat andere personen zonder zijn toestemming niet interfereren met zijn vrijheid en welzijn (Gewirth 1978, 137-38, eigen vertaling) ${ }^{15}$

Met andere woorden: ook wanneer iemand besluit een einde te maken aan het leven, moet haar vrijheid en haar welzijn worden gerespecteerd, zolang haar besluit tot zelfdoding tenminste telt als een handeling 'in strikte zin'. De keuze om een einde te maken aan het leven moet bijvoorbeeld niet het gevolg zijn van dwang of manipulatie, en het mag ook geen 'geforceerde' keuze zijn, zoals: 'je geld of je leven' (Gewirth 1978: 32). Wanneer we vervolgens iemand de mogelijkheid ontnemen om naar eigen inzicht te handelen, inclusief de keuze om tot zelfdoding over te gaan, dan begeven we ons dus op moreel problematisch terrein. Maar de immoraliteit rondom zelfdoding heeft in dit geval dus niet zozeer te maken met een plicht die een individu ten aanzien van zichzelf niet nakomt, maar eerder de plicht van de ander om haar (laatste) vrije keuze te ontnemen (Gewirth 1978: 264-66).

Is er dan niets moreel problematisch aan zelfdoding bij een benadering waarbij de aanname dat een rationeel leven intrinsiek waardevol is wordt losgelaten? Jawel, namelijk wanneer iemands plan om een einde te maken aan het leven geen echte vrije keuze is en dus niet telt als handeling in strikte zin'. Op zichzelf is dat natuurlijk niet direct moreel problematisch: we maken wel vaker keuzes die strikt genomen geen echte keuzes zijn. Wanneer vlak naast mij een hijskraan neerstort, dan ren ik naar de uitgang. In zo'n geval is de keuze om te rennen geen echte keuze, ik kon niet anders (aannemende dat ik wilde blijven leven). Maar daarmee is nog niet gezegd dat hier iets moreel problematisch aan de hand is. Echter, wanneer de onvrijheid van een handeling niet het gevolg is van brute pech, maar het gevolg is

15 Ik ga hier verder niet in op de exegetische vraag in hoeverre dit is wat Kant bedoelde, en/of in hoeverre dit alternatief echt telt als een 'Kantiaans' alternatief. 
van het handelen van anderen of van hoe bepaalde instituties zijn ingericht, dan verandert mogelijk het verhaal. Wanneer iemand in de tragische situatie terechtkomt niets anders meer te kunnen willen behalve te stoppen met willen, en deze tragische situatie is het gevolg van gevoelens van eenzaamheid en zinloosheid die op haar beurt het gevolg zijn van falende ouderenzorg, heersende stereotypes over ouderen, en de onmogelijkheid voor ouderen om in de samenleving nog ergens aan mee te kunnen doen of bij te dragen, dan is er wel degelijk iets moreel problematisch aan de zelfdoding in kwestie. Ook hier lijkt het het geval dat wat moreel problematisch is aan de situatie niet zozeer te maken heeft met het feit dat het individu een bepaalde morele plicht ten aanzien van zichzelf niet nakomt (het respecteren van haar rationele natuur), maar met het handelen van anderen, in de breedste zin van het woord. Moreel juist handelen zou, deze denkrichting volgend, niet inhouden dat we zelfdoding moreel afkeuren of zelfs verbieden, maar iets proberen te doen aan de onderliggende problematiek die ertoe leidt dat personen niets anders meer willen dan nooit meer te willen.

Ik kan hier niet daadwerkelijk argumenteren voor deze standpunten het moge duidelijk zijn dat het bovenstaande niet meer is dan een zeer ruwe schets. Een beter uitgewerkt alternatief zal bewaard moeten worden voor een volgende keer. Het belangrijkste punt voor nu is dat de aanname dat elk rationeel leven waardevol is hetgeen is dat voor problemen lijkt te zorgen wanneer het gaat om het legitimeren van (bepaalde) zelfdodingen, en dat het loslaten van deze aanname wellicht alternatieve (liberalere) benaderingen mogelijk maakt.

\section{Conclusie}

In dit artikel heb ik gekeken naar bestaande argumenten die een aantal hedendaagse Kantianen hebben aangevoerd om tot een 'milder' oordeel te komen wat betreft de legitimiteit van zelfdoding. Volgens wat ik het 'uitzonderingsargument' heb genoemd, is zelfdoding legitiem wanneer er geen sprake meer is van een 'rationeel leven' dat moreel respect verdient. Het succes van het argument hangt af van hoe we de notie van een rationeel leven begrijpen. Ik heb beargumenteerd dat er bij verschillende auteurs daaromtrent een verschuiving plaatsvindt tussen 'minimale' en 'substantiele' concepties daarvan. De meeste 'milde' Kantianen beginnen doorgaans met een minimale interpretatie van wat het betekent een rationeel leven te leiden, zoals het beschikken over de capaciteit om kritisch te kunnen reflecteren op je eigen driften en verlangens. Maar als we vervolgens kijken 
naar de redenen die aangevoerd om bepaalde instanties van zelfdoding als legitiem te zien, wordt vaak plots een beroep gedaan op een 'dikkere' invulling van onze rationele natuur.

Maar noch een minimale, noch een substantiële interpretatie stelt de milde Kantiaan in staat een midden in te nemen waarbij bepaalde zelfdodingen moreel toelaatbaar worden geacht, en anderen niet. Als het hebben van een rationeel leven zeer minimale eisen heeft, dan is het moeilijk vol te houden dat personen die ondraaglijk lijden geen rationeel leven leiden, in minimale zin. Als dat zo is, heb ik beargumenteerd, valt zelfdoding niet te legitimeren, want er is nog altijd sprake van een rationeel leven dat moreel respect verdient en waarop morele plichten van toepassing zijn. Maar wanneer we meer condities toevoegen en de notie van een rationeel leven substantiëler invullen - en deze bijvoorbeeld narratief begrijpen in termen van het kunnen vertellen van een levensverhaal - dan worden weer veel te veel zelfdodingen legitiem. De milde Kantiaan schiet dan door naar het liberale eind van het spectrum, en verliest de mogelijkheid een middenpositie in te nemen en bepaalde zelfdodingen alsnog als moreel problematisch te bezien. Bovendien is het, wanneer men een substantiële interpretatie van de notie van een rationeel leven verdedigt, niet meer duidelijk dat we nog te maken hebben met een universele beschrijving die op iedereen van toepassing is, in plaats van een contingente (westerse) beschrijving van hoe sommige personen zichzelf begrijpen. Kortom, op een minimale interpretatie is het bereik van toegestane zelfdoding dus te klein, op een substantiële interpretatie te ruim.

Ik heb tot slot nog de vraag proberen te beantwoorden waarom een Kantiaanse middenpositie instabiel lijkt te zijn. Daarbij heb ik gesuggereerd dat het in het begin mogelijk al mis ging, namelijk, met de moreel realistische aanname dat het hebben van een rationeel leven of een praktische natuur van intrinsieke of onconditionele waarde is. Wanneer we deze aanname zouden laten varen, opent zich de weg voor een alternatieve benadering ten aanzien van zelfdoding, waarbij zelfdoding niet in de regel moreel verboden is omdat het een 'disrespect' inhoudt ten aanzien van iemands rationele leven.

\section{Dankwoord}

Dank aan Sem de Maagt, Katrien Schaubroeck en twee anonieme referenten van het ANTW voor zeer behulpzame commentaren. Dit artikel is tot stand gekomen met hulp van een fellowship van de Niels Stensen Foundation. 


\section{Bibliografie}

Archard, D. (1990) Freedom Not to Be Free: The Case of the Slavery Contract in J. S. Mill's on Liberty, The Philosophical Quarterly 40, pp. 453-65. https://doi.org/10.2307/2220110.

Brassington, I. (2006) Killing People: What Kant Could Have Said about Suicide and Euthanasia but Did Not, Journal of Medical Ethics 32 (10), pp. 571-74. https://doi.org/10.1136/jme.2005.015420.

Cholbi, M. (2010) A Kantian Defense of Prudential Suicide, Journal of Moral Philosophy 7(4), pp. 489-515. https://doi.org/10.1163/174552410X511455.

Cholbi, M. (2015) Kant on Euthanasia and the Duty to Die: Clearing the Air, Journal of Medical Ethics 41 (8), pp. 6o7-10. https://doi.org/10.1136/medethics-2013-101781.

Cooley, D.R. (2007) A Kantian Moral Duty for the Soon-to-Be Demented to Commit Suicide, The American Journal of Bioethics 7(6), pp. 37-44. https://doi.org/10.108o/15265160701347478.

Gewirth, A. (1978) Reason and Morality. Chicago: University of Chicago Press.

Gunderson, M. (2004) A Kantian View of Suicide and End-of-Life Treatment, Journal of Social Philosophy 35(2), pp. 277-287.

Hartogh, G. den (2013) Klaar Met Leven: De Open Vragen, Podium Voor Bio-Ethiek 20 (3), pp. 4-8.

Hartogh, G. den (2016) Two Kinds of Suicide, Bioethics 3o(9), pp. 672-80.

Hill, T.E. (1991) Self-Regarding Suicide: A Modified Kantian View, in: Autonomy and Self-Respect. Cambridge: Cambridge University Press, pp. 85-103.

Kant, I. (1797) Kant: The Metaphysics of Morals. Cambridge: Cambridge University Press.

Kant, I. (1997) Lectures on Ethics, translated and edited by P. Heath and J.B. Schneewind. Cambridge: Cambridge University Press.

Korsgaard, C.M. (1985) Kant's Formula of Universal Law, Pacific Philosophical Quarterly 66(1-2), pp. 24-47.

Korsgaard, C.M. (1986) Kant's Formula of Humanity, Kant-Studien 77, pp. 183-202.

Korsgaard, C.M. (1996) The Sources of Normativity. Cambridge: Cambridge University Press.

Korsgaard, C.M. (2009) Self-Constitution: Agency, Identity, and Integrity. Oxford: Oxford University Press.

Langton, Rae (1992) Duty and Desolation, Philosophy 67, pp. 481-505.

Maagt, S. de (2017) Constructing Morality: Transcendental Arguments in Ethics. Dissertation, January $27,2017$.

Mertens, T.J.M. (red.) (2008) I. Kant, Fundering Voor de Metafysica van de Zeden. 5 e Herziende En Uitgebreide Uitgave. Inleiding, Vertaling En Annotaties. Amsterdam: Boom.

Mertens, T.J.M. (2017) Kant over Zelfmoord, Filosofie \& Praktijk 38, pp. 5-21.

Mill, J.S. (1859/2003) Utilitarianism and On Liberty, edited by Mary Warnock. Malden, MA: Blackwell Publishing.

Nussbaum, M. (1995) Aristotle on Human Nature and the Foundations of Ethics, in: J.E.J. Altham and Ross Harrison (red.) World, Mind, and Ethics: Essays on the Ethical Philosophy of Bernard Williams. New York: Cambridge University Press, pp. 86-131.

Nyholm, S. (2016) On Kant's Idea of Humanity as an End in Itself, European Journal of Philosophy 24(2), pp. 358-74. https://doi.org/10.1111/ejop.12057.

Pasman, H.R.W., M.L. Rurup, D.L. Willems, and B.D. Onwuteaka-Philipsen (2009) Concept of Unbearable Suffering in Context of Ungranted Requests for Euthanasia: Qualitative Interviews with Patients and Physicians, BMJ: British Medical Journal 339(7732), pp. 1235-1237. https://doi.org/10.1136/bmj.b4362.

Rawls, J. (1971) A Theory of Justice. Cambridge, Mass: Harvard University Press.

Rawls, J. (1996) Political Liberalism. New York: Columbia University Press. 
Schwan, D. (2013) J.S. Mill on Coolie Labour and Voluntary Slavery, British Journal for the History of Philosophy 21(4), pp. 754-766.

Strawson, G. (2004) Against Narrativity, Ratio 17(4), pp. 428-52.

Uleman, J. (2016) No King and No Torture: Kant on Suicide and Law, Kantian Review 21(1), pp. 7710o. https://doi.org/10.1017/S136941541500031X.

Vanhaute, L. (2009) Taboe Op Doden of Inconsistentie in Het Willen? Govert Den Hartoghs Euthanasievoorbeeld Anders Bekeken, Algemeen Nederlands Tijdschrift Voor Wijsbegeerte 101(3), pp. 211-213.

Velleman, J.D. (1999) A Right of Self-Termination? Ethics 109(3), pp. 6o6-28.

Velleman, J.D. (2015) Beyond Price: Essays on Birth and Death. Cambridge, UK: Open Book Publishers.

\section{Over de auteur}

Fleur Jongepier is werkzaam als universitair docent toegepaste ethiek aan de Radboud Universiteit Nijmegen. Daarvoor ontving ze een Niels Stensen Fellowship om als postdoc te kunnen werken aan de Universiteit van Cambridge aan het project The Role and Value of Self-Knowledge in Contemporary Liberalism. Ze schreef haar proefschrift over de (psychische en morele) condities van zelfkennis, en publiceerde verschillende artikelen, onder andere over narrativiteit, zelfkennis en psychotherapie, 'mental agency' en zelfbewustzijn. Samen met Sem de Maagt en Leon de Bruin schreef zij het boek IK. Filosofie van het Zelf (Uitgeverij Boom). Ze is tevens mede-oprichter en hoofdredacteur van de filosofieblog Bij Nader Inzien, www.bijnaderinzien.org. 